\title{
MC4R wt Allele
}

National Cancer Institute

\section{Source}

National Cancer Institute. MC4R wt Allele. NCI Thesaurus. Code C131299.

Human MC4R wild-type allele is located in the vicinity of $18 \mathrm{q} 22$ and is approximately $2 \mathrm{~kb}$ in length. This allele, which encodes melanocortin receptor 4 protein, is involved in ligandstimulated signaling. Mutation of the gene is associated with autosomal dominant obesity. 